\title{
The informed consent in clinical trials in school dental units: Impact analysis
}

\author{
Consimţământul informat în studiile clinice desfăşurate în cabinetele \\ şcolare de medicină dentară - Analiză de impact
}

\author{
Cristian Funieru' ${ }^{1}$ Ruxandra Ionela Sfeatcu², Silviu Mirel Pițuru ${ }^{3}$ \\ ${ }^{1}$ Disciplina de Prevenţie Orodentară, Facultatea de Medicină Dentară, \\ Universitatea de Medicină şi Farmacie „Carol Davila“, Bucureşti, România \\ ${ }^{2}$ Disciplina de Sănătate Orală şi Stomatologie Comunitară, Facultatea de Medicină Dentară, \\ Universitatea de Medicină şi Farmacie „Carol Davila“, Bucureşti, România \\ ${ }^{3}$ Disciplina de Organizare Profesională şi Legislaţie Medico-Dentară, Facultatea de Medicină Dentară, \\ Universitatea de Medicină şi Farmacie „Carol Davila“, Bucureşti, România
}

\begin{abstract}
Introduction. The informed consent is a very important and needful issue for any medical procedure, treatment or clinical trial. In case of minor patients or those without capacity of discernment, the legal owners must sign the informed consent.

Materials and methods. The present study is an analysis of the informed consent forms used in 3 studies conducted between 2006 and 2016 in the schools dental units in Bucharest, which had as main objective the examination of the oral health status of schoolchildren aged between 11 and 14 years, as well as many various correlations related to it.

Results. The parents approved (69\%), refused (17\%) their children being part of these studies and others put some conditions. The main reason for the parents' refusal regarding the clinical trials was the lack of confidence in dental tools' sterilization process.

Conclusions. The informed consent has some limits when dealing with minor patients. It is very important for school dentists, for those who work in private dental clinics or for the examiners in clinical trials that parents always sign the informed consent.
\end{abstract}

Keywords: informed consent, school dental units, impact

\section{REZUMAT}

Introducere. Consimţământul informat este un document indispensabil actului medical în sine sau cercetării în domeniul medical. Atunci când pacienţii sunt minori sau lipsiţi de discernământ, consimţământul informat trebuie obţinut de la aparţinătorii acestora.

Materiale și metodă. Prezentul studiu reprezintă o analiză a consimţămintelor folosite în 3 studii desfăşurate între anii 2006 şi 2016 în cabinetele dentare şcolare din Municipiul Bucureşti, care au avut ca obiectiv principal determinarea şi stabilirea de diverse corelaţii legate de starea de sănătate orală a elevilor cu vârste cuprinse între 11 şi 14 ani.

Rezultate. Aparţinătorii au acceptat participarea copiilor în aceste studii (69\%), o parte au refuzat (17\%), iar alţii au pus anumite condiţii. Principalul motiv de refuz al aparţinătorilor a fost neîncrederea în sterilizarea instrumentarului de consultaţie.

Concluzii. Consimţământul informat ridică multe probleme şi are o serie de limite atunci când avem de-a face cu pacienţii minori. Foarte important pentru medicii dentişti şcolari, pentru cei care activează în cabinetele private de medicină dentară sau pentru examinatorii din studiile clinice este faptul că formularele de consimţământ informat în cazul pacienţilor minori trebuie semnate de către aparţinătorii acestora.

Cuvinte cheie: consimţământ informat, cabinete dentare şcolare, impact 


\section{INTRODUCERE}

Pentru orice tip de investigație clinică sau paraclinică, îngrijire medicală sau tratament cu potențial de risc avem nevoie de acordul în scris al pacientului, certificat prin semnătura sa (consimțământul pacientului). Cu excepția situației de urgență medicală care pune în pericol viața pacientului, aşa cum este ea definită în lege, acest acord este obligatoriu, dar şi în aceste cazuri este necesară completarea postintervenție a unui raport de urgență, raport care justifică lipsa consimțământului informat. În formularul de acord informat trebuie menționat în mod obligatoriu numele medicului sau al medicilor care sunt răspunzători de actul medical. Medicul trebuie astfel să informeze pacientul într-un limbaj accesibil, pe înțelesul lui, cu privire la scopul intervenției medicale folosite, riscul potențial al acesteia, prognosticul afecțiunilor fără aplicarea tratamentului sau metodelor de îngrijire medicală/ profilactică recomandate, posibilele consecințe medico-sociale, psihologice, economice etc., precum şi privind variantele alternative de tratament, îngrijire medicală şi dreptul la o a doua opinie.

Pacientul îşi poate exprima liber consimțământul dacă nu este lipsit de discernământ sau dacă are peste 18 ani (1). Conform ultimelor prevederi legale, atunci când avem de-a face cu pacienți minori, consimțământul informat trebuie obținut de la unul dintre părinţi ori de la reprezentantul legal al minorului (desemnat în urma unei hotărâri judecătoreşti) sau, în lipsa acestora, de la ruda cea mai apropiată, până la gradul 4 inclusiv (2). Formularea , în lipsa acestora" se referă mai degrabă la lipsa părinților pe termen lung şi nu la momentul desfăşurării actului medical, de exemplu, atunci când aceştia lipsesc fiind plecați la muncă în altă țară.

Pacientul sau reprezentantul legal pot accepta investigația/tratamentul sau o/îl pot refuza. Refuzul pacientului se perfectează prin înscrierea respectivă în documentația medicală, cu indicarea consecințelor posibile şi se semnează de către pacient sau de reprezentantul său legal (ruda apropiată), atunci când acesta este lipsit de discernământ. Dacă actul medical în sine face parte dintr-un studiu, atunci pacientul sau reprezentantul legal trebuie să îşi dea acordul şi pentru publicarea datelor personale (sub protecția anonimatului), fotografiere, filmare etc., în cazul în care studiul prevede aşa ceva.
Un aspect foarte important de precizat este acela că, începând cu anul 2016, Ministerul Sănătăţii a pus la dispoziție un formular unic de consimţământ informat.

Prezentul studiu analizează impactul consimțământului informat asupra părinților/reprezentanților legali ai elevilor din Bucureşti, ai căror copii au fost cuprinşi în 3 studii desfăşurate în cabinetele şcolare dentare.

\section{MATERIALE ŞI METODĂ}

Studiul a analizat impactul pe care 1-a avut consimţământul informat asupra părinţilor/aparținătorilor legali ai elevilor cuprinşi în 3 studii efectuate în cabinetele şcolare din Municipiul Bucureşti, studii care au avut în vedere efectuarea de consultații şi extragerea datelor referitoare la cariile dentare, afecțiunile gingivo-parodontale, anomaliile dentomaxilare, starea igienei orale etc. Studiile s-au desfăşurat între 2006 şi 2016 de către cadre didactice ale Facultății de Medicină Dentară, din cadrul Universității de Medicină şi Farmacie „Carol Davila“, cu acordul Autorităţii de Sănătate Publică/Administrației Spitalelor şi Serviciilor Medicale Bucureşti şi al Inspectoratului Şcolar al Municipiului Bucureşti. Prelucrarea informațiilor referitoare la cele 1.247 de consimțăminte informate reprezintă date finale şi parțiale (în limita în care s-au putut recupera) ale acestor 3 studii care au avut un formular de consimțământ informat similar. Vârstele copiilor cuprinşi în studiu au variat între 11 şi 14 ani şi au reprezentat în principal clasele a $\mathrm{V}$-a şi a VI-a. Atât protocoalele clinice ale acestor studii, cât şi formularul de consimțământ informat au fost aprobate de Comisia de Etică a Universității de Medicină şi Farmacie „Carol Davila“ din Bucureşti. Formularul de consimțământ informat (inclusiv anexa sa) a conţinut informațiile necesare pentru aparținători, în care era precizat că nu se vor efectua niciun fel de intervenții terapeutice pe parcursul protocolului clinic şi că, în urma examinărilor, se va face o prelucrare statistică a datelor. Trebuie menționat că în acea perioadă nu exista niciun formular unic acceptat cum este în ziua de astăzi. Aparţinătorii au fost rugați să precizeze şi motivul aceptării/rezufuzului efectuării consultației. 


\section{REZULTATE}

În Fig. 1 este redat răspunsul aparținătorilor obținut în urma distribuirii consimțămintelor informate.

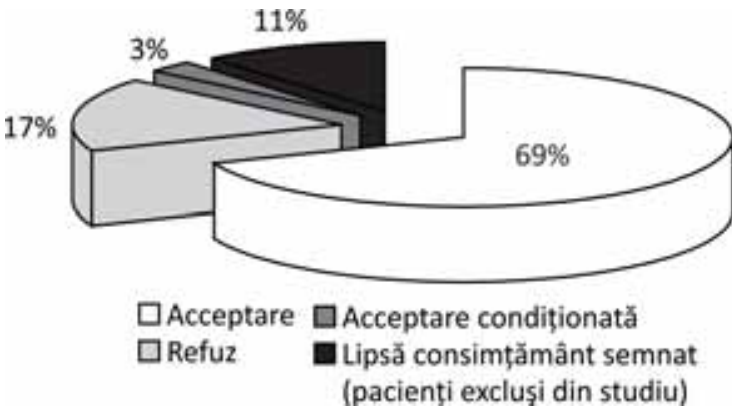

FIGURA 1. Impactul consimțământului informat asupra aparținătorilor elevilor cuprinşi în cele 3 studii

Se observă că rata de refuz este una acceptabilă (17\%). Motivele care au stat la baza acceptării, refuzului sau condiționării din partea părinților sunt prezentate în Fig. 2 şi Tabelul 1. Astfel, în Fig. 2, raportarea procentuală se referă la cei 860 de aparținători care au acceptat participarea elevilor în studii (au putut fi bifate mai multe răspunsuri), iar în Tabelul 1, aparținătorii care au refuzat participarea: $212(17 \%)$ şi cei care au condiționat-o $37(3 \%)$ au putut alege doar un singur motiv principal, care a stat la baza deciziei lor.

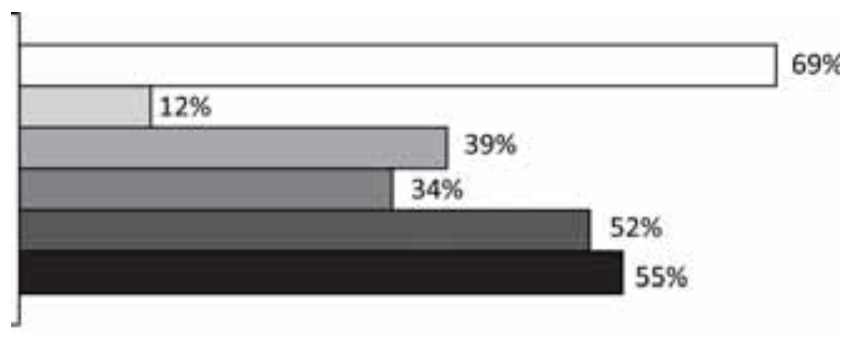

\footnotetext{
Aflarea informatiilor medicale

Nu au răspuns la intrebare

Increderea in competența și pregătirea medicilor dentişti examinatori

Implicarea autoritătilor

Oferirea de produse pentru igiena orală

Nu se fac manevre terapeutice
}

FIGURA 2. Motivarea acceptării includerii în studiu (au putut fi bifate mai multe răspunsuri)

TABELUL 1. Motivele refuzului şi condiționării includerii în studiu (s-a putut bifa doar un singur răspuns)

\begin{tabular}{|l|c|}
\hline Motivarea refuzului & Nr. cazuri \\
\hline Neîncrederea în examinator & 42 \\
\hline Consultul face parte dintr-un studiu științific & 65 \\
\hline Neîncrederea în sterilizarea instrumentarului & 75 \\
\hline Au refuzat să răspundă & 30 \\
\hline TOTAL & $\mathbf{2 1 2}$ \\
\hline Motivarea condiționării & Nr. cazuri \\
\hline Asigurări pentru o sterilizare eficientă & 16 \\
\hline Fără efectuarea de fotografii & 9 \\
\hline Cu comunicarea expresă a rezultatelor consultului & 12 \\
\hline TOTAL & $\mathbf{3 7}$ \\
\hline
\end{tabular}

\section{DISCUŢII}

Rezumând cele prezentate mai sus, se poate observa că rata refuzului în astfel de studii întreprinse în cabinetele dentare şcolare este una rezonabilă, sub $20 \%$. Trebuie precizat însă că această rată de refuz sau cea de acceptare (de aproximativ 70\%) nu se referă la consultul de rutină sau la manoperele efectuate de medicii dentişti şcolari în cabinetele şcolare, ci la interferența cu un examinator extern sau cu desfăşurarea unui studiu. Aflarea informațiilor medicale şi absența tratamentelor au fost principalele motive care au stat la baza acceptării. Cauzele principale care au determinat părinții sau aparținătorii să refuze includerea în studiu au fost neîncrederea în sterilizarea instrumentarului şi tocmai faptul că acest consult făcea parte dintr-un studiu ştiinţific. Chiar şi condiţionarea a avut ca principal motiv sterilizarea instrumentarului. Acest aspect poate fi explicat prin faptul că în spaţiul media şi în presă au apărut tot mai multe reportaje şi articole legate de transmiterea diverselor boli de natură infecțioasă în cabinetul de medicină dentară. Faptul că aparținătorii au fost înştiințaţi că examinarea copilului va avea ca rezultat prelucrarea statistică a datelor a atras într-o oarecare măsură frica de ,efectul de cobai“. Desigur, apreciem că rata de refuz s-ar fi situat la o valoare mult mai ridicată în cazul în care studiile ar fi fost de tip experimental, ci nu doar simple, observaționale.

După cum se ştie, legislația românească protejează participarea pacientului minor în cercetarea ştiințifică şi învățământul medical, acest lucru fiind condiţionat de existența consimțământului informat semnat de aparținătorul său şi de faptul ca acțiunile să fie în interesul şi beneficiul pacientului $(3,4)$. În cazul în care copiii sunt examinați în cadrul unei instituții, cum este şcoala, în cabinetul şcolar dentar, pe lângă consimţământul informat, cei care desfăşoară studiile trebuie să obțină aprobarea atât a Inspectoratului Şcolar de pe raza căruia se află şcoala, cât şi a organizaţiei care coordonează cabinetele medicale şi dentare şcolare (în cazul Municipiului Bucureşti, Administrația Spitalelor şi Serviciilor Medicale Bucureşti).

\section{CONCLUZII}

Analiza legislativă şi de impact a utilizării consimțământului informat duce la identificarea unor 
probleme, dar şi a unor limite în aplicarea acestuia în cercetarea ştiințifică ce implică pacienți minori. Copiii sunt vulnerabili atunci când vine vorba de implicarea lor în cercetarea medicală, din cauza vârstei şi prin faptul că nu pot oferi un consimțământ informat pentru actul medical exercitat asupra lor. Conform legislației din țara noastră, dar şi a celei europene, părinții, reprezentanții lor legali sau, în unele cazuri, rudele apropiate au dreptul de a da consimțământul informat în numele copiilor. Medi- cul dentist care desfăşoară studii în cabinetele dentare şcolare sau chiar însuşi medicul dentist din rețeaua şcolară trebuie să posede acest consimțământ informat în vederea efectuării actului medical de orice fel.

\section{Mulțumiri}

Dorim să mulțumim companiei Colgate-Palmolive România pentru sprijinul acordat.

Conflict of interest: none declared

\section{BIBLIOGRAFIE}

1. Legea Nr. 95 din 14 aprilie 2006: art. 649-651;

2. Ordinul nr. $1411 / 2016$ privind modificarea şi completarea Ordinului ministrului Sănătăţi publice nr. 482/2007 privind aprobarea Normelor metodologice de aplicare a titlului XV „Răspunderea civilă a personalului medical şi a furnizorului de produse şi servicii medicale, sanitare şi farmaceutice" din
Legea nr. 95/2006 privind reforma în domeniul sănătăţii; art. $8(3)$;

3. Legea drepturilor pacientului nr. 46/2003; art. 19;

4. Butnariu A., Lupu I., Buta M. Consimţământul informat în practica pediatrică şi în cercetarea vizând copilul. Revista Română de Bioetică 2009; 7(1):38-46. 